Jurnal

Kardiologi Indonesia

J Kardiol Indones. 2013;34:204-6

ISSN 0I 26/3773

\title{
Torsades de Pointes pada pasien Hipokalemia: Peranan Afterdepolarization pada mekanisme Takiaritmia
}

\author{
Alexander Edo Tondas, Yoga Yuniadi
}

\section{Kasus}

Seorang wanita usia 56 tahun, dengan riwayat gagal jantung dalam pengobatan dengan obat diuretik furosemid, mengalami muntaber selama 3 hari terakhir. Saat tiba di UGD, EKG dengan irama sinus tiba-tiba mengalami degenerasi menjadi takikardia QRS lebar polimorfik saat perekaman. Presentasi hemodinamik pasien menjadi tidak stabil sehingga diputuskan untuk dilakukan kardioversi elektrik. Setelah defibrilasi, irama jantung kembali menjadi irama sinus dan hasil laboratorium menujukkan hipokalemia berat $(2,4$ meq/L). Setelah koreksi potassium dan perawatan, pasien membaik kemudian dipulangkan. Apa mekanisme tercetusnya torsades de pointes pada pasien ini?

\section{Diskusi}

Perubahan paling dini yang dapat diamati pada EKG pasien hipokemia adalah penurunan amplitudo gelombang T. Pada level potassium yang lebih rendah, dapat ditemukan depresi segmen ST dan inversi gelombang

\section{Alamat korespondensi:}

Dr. dr. Yoga Yuniadi, SpJP, Divisi Aritmia, Departemen Kardiologi dan Kedokteran Vaskuler FKUI dan Pusat Jantung Nasional Harapan, Kita, Jl S Parman Kav 87 Jakarta I I420, E-mail: yogayun@yahoo.com
T, sementara interval PR dapat memanjang disertai peningkatan amplitudo gelombang P. Gelombang $U$ dideskripsikan sebagai defleksi positif setelah gelombang $T$, umumnya paling baik terlihat pada sadapan mid-prekordial (mis. V2 dan V3). Apabila amplitudo gelombang $U$ melebihi gelombang $T$, seperti tampak pada Gambar 1, umumnya level potassium serum sudah lebih rendah dari $3 \mathrm{mEq} / \mathrm{L}$. Pada hipokalemia yang sangat berat, fusi gelombang $T$ dan $U$ dapat membentuk gelombang U raksasa, dimana gelombang $T$ yang lebih kecil tertutupi keberadaannya. Interval QT yang seolah-olah memanjang dapat terlihat pada EKG, yang sebenarnya adalah interval QU tanpa T wave. Gelombang U diduga merupakan manifestasi repolarisasi dari otot papilaris atau serat Purkinje. Hipokalemia berat juga dapat menyebabkan berbagai takiaritmia, termasuk takikardia/fibrilasi ventrikel.

Mekanisme utama terjadinya takiaritmia adalah otomatisitas (automaticity), reentri, dan aktivitas terpicu (triggered activity). Aktivitas terpicu adalah inisiasi impuls pada serat jantung yang disebabkan oleh afterdepolarization (getaran membran potensial) yang cukup besar, melewati batas ambang aktivasi, sehingga menghasilkan aksi potensial baru. Afterdepolarization dapat terjadi selama fase repolarisasi dari aksi potensial (early afterdepolarization[EAD]) atau setelah selesainya fase repolarisasi (delayed after depolarization [DAD]).

DAD lebih cenderung muncul pada kondisi takikardia, dan dipercaya menyebabkan aritmia ventrikular pada intoksikasi digitalis, VT outflow tract, ekses 


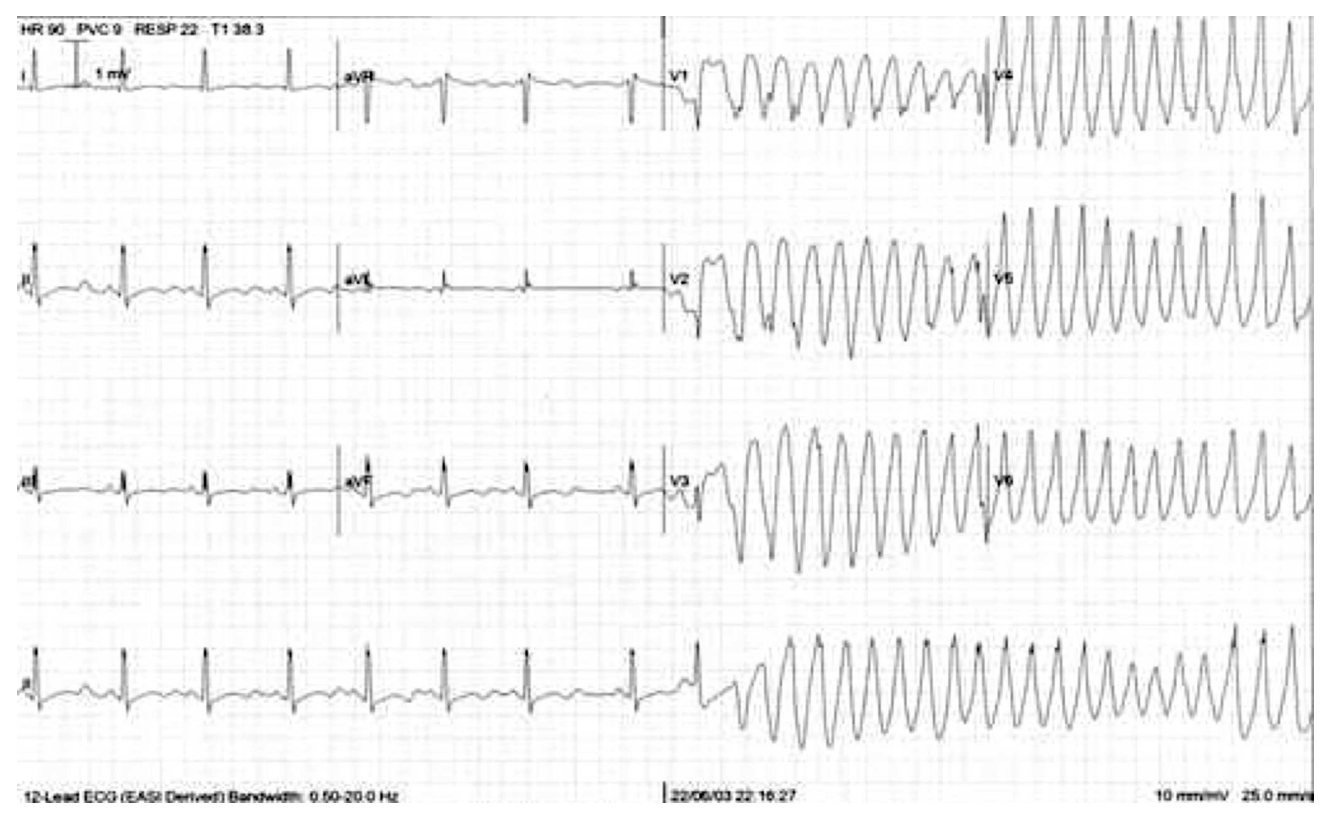

Gambar 1. Tampak suatu irama sinus dengan gelombang $U$ yang prominen, kemudian tibatiba terjadi transisi menjadi torsades de pointes

katekolamin, serta VT akibat infark miokard akut. DAD terjadi selama fase IV dari aksi potensial, dimana terdapat kondisi overload Ca intraselular akibat keterlibatan arus pertukaran $\mathrm{Na} / \mathrm{Ca}\left(\mathrm{I}_{\mathrm{Na} / \mathrm{Ca}}\right)$ dan arus aktivasi Ca non spesifik $\left(\mathrm{I}_{\mathrm{NS}}\right)$. Bila DAD berhasil mencetuskan aksi potensial secara berulang-ulang maka akan terjadi takikardia yang berkelanjutan.

EAD, dapat terjadi pada fase II (plateau EAD) yang disebabkan oleh arus masuk Ca tipe-L ( $\mathrm{I}_{\mathrm{CaL}}$ ) atau fase III (late $E A D$ ) oleh $\mathrm{I}_{\mathrm{Na} / \mathrm{Ca}}$ yang juga merupakan penyebab dari DAD. EAD terutama terlibat dalam mekanisme torsades de pointes yang diinduksi obat atau abnormalitas elektrolit dan beberapa varian dari sindrom QT panjang (LQTS). Kondisi yang memudahkan timbulnya EAD adalah pemanjangan aksi potensial, yang bermanifestasi pada EKG sebagai prolongasi interval QT. Hipomagnesemia, hipokalemia, bradikardia dan obat (terutama antiaritmia golongan IA, III) merupakan predisposisi timbulnya EAD (proaritmia). Gangguan dispersi transmural dari repolarisasi akibat EAD dapat membuka jendela yang rentan terhadap reentri.

Studi pada hewan menunjukkan bahwa aritmogenisitas akibat hipokalemia disebabkan oleh pemanjangan repolarisasi ventrikular, perlambatan konduksi dan aktivitas pacu jantung yang abnormal. Pemanjangan repolarisasi pada kondisi hipokalemik disebabkan oleh hambatan dari arus keluar potassium $\left(\mathrm{I}_{\mathrm{K}}\right)$ yang secara paradoks disebabkan oleh turunnya $\mathrm{K}^{+}$ekstraselular. Hal ini seringkali mencetuskan EAD. Perlambatan konduksi diakibatkan oleh hiperpolarisasi membran dan kenaikan ambang eksitasi. Aktivitas pacu jantung abnormal terkait dengan peningkatan depolarisasi diastolik pada serat Purkinje, serta DAD akibat overload $\mathrm{Ca}^{2+}$ sekunder dari inhibisi pompa $\mathrm{Na}^{+} \mathrm{K}^{+}$dan stimulasi arus pertukaran $\mathrm{Na}^{+} \mathrm{Ca}^{2+}$. Efek hipokalemia terhadap berbagai lokasi pada ventrikel sifatnya tidak seragam sehingga terdapat gradien repolarisasi spasial yang memudahkan timbulnya blok konduksi searah. Prolongasi aksi potensial

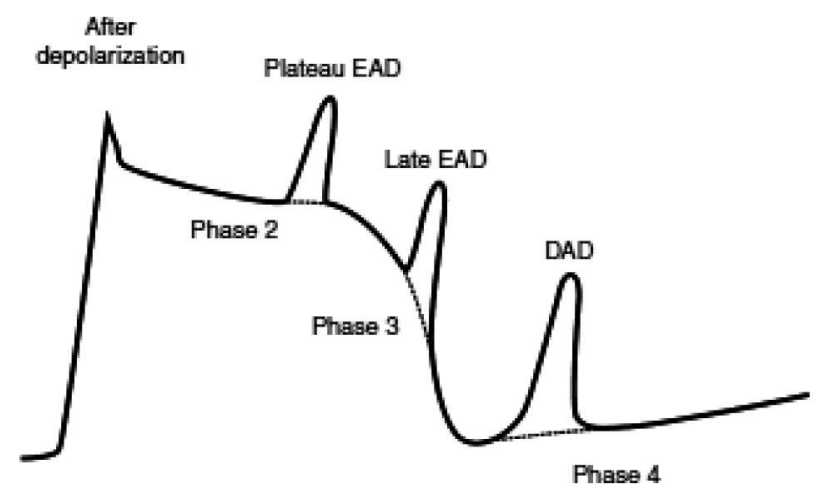

Gambar 2. Klasifikasi afterdepolarization 
akan memendekkan periode refrakter efektif (ERP), yang membuat fase akhir repolarisasi rentan terhadap re-eksitasi ventrikel. ERP yang pendek dan konduksi yang lambat, sangat memfasilitasi terjadinya reentri. Hubungan antara faktor pencetus (afterdepolarization terutama EAD, getaran prepotensial pada serat Purkinje) dan substrat elektrofisiologis yang tepat (blok konduksi satu arah, pemendekan eksitasi dan pemanjangan interval kritis untuk reeksitasi ventrikel) berkontribusi terhadap mekanisme terjadinya takiaritmia fatal pada pasien hipokalemia.

\section{Daftar Pustaka}

1. Diercks DB, Shumaik GM, Harrigan RA, Brady WJ, Chan TC. Electrocardiographic manifestations: electrolyte abnormalities.
J Emerg Med 2004;27(2):153-60.

2. El-Sherif N, Turitto G. Electrolyte disorders and arrythmogenesis. Cardiol J 2011;18(3):233-

3. Glancy DL, Wiklow FE, Rochon BJ. Electrocardiogram after 2 weeks of diarrhea. Proc (Bayl Univ Med Cent) 2010;23(2):1734.

4. Pérez Riera AR, Ferreira C, Filho CF, et al. The enigmatic sixth wave of the electrocardiogram: the $U$ wave. Cardiol J 2008;15 (5): 408-21.

5. Natale A, Wazni O, eds. Handbook of Cardiac Electrophysiology. 1st Ed. London:Informa Healhcare; 2007.

6. Issa ZF, Miller JM, Zipes DP, eds.Clinical Arrhytmology and Electrophysiology : Companion to Braunwald's Heart Disease.2nd Ed. Philadelphia : Elsevier; 2012

7. Osadchii OE. Mechanisms of hypokalemia-induced ventricular arrhytmogenicity. Fundam Clin Pharmacol. 2010 Oct;24(5):547-59 